\title{
Servant Leadership: A Taxonomic Approach towards Systematic Literature Review
}

\author{
Muhammad Azeem Qureshi ${ }^{1 *}$ \\ Abdur Rahman Aleemi ${ }^{2}$ \\ Syed Irfan Hyder ${ }^{3}$
}

\begin{abstract}
Connection between inferior leadership and massive business meltdown and inadequacy of seasoned leadership models create an urge to seek leadership equipped with ethical behavior, concern for subordinates, all the stakeholders and the society as a whole. This literature survey examines existing literature addressing servant leadership theory. Servant leadership theory has not yet been legitimize as a mainstream leadership theory therefore, it is worthy to examine its antecedents, outcomes and different mediating and moderating mechanisms to have in-depth knowledge of servant leadership concept and to understand how it differs from other mainstream leadership theories. This study analyzed the literature using descriptive approach as proposed by Turnnidge \& Côté (2016). The study has been carried out in three phases. First phase is concerned with screening of abstracts and citations related to variable of interests, in second phase, peer discussion was made to retain valuable literature and exclusion of literature which does not fall in set criterion. In third phase, full text of articles and relevant literature were reviewed which were potentially related to and are of interest. It was found that servant leadership is a different concepts which is more comprehensive and predicts more positive outcomes than its predecessor leadership models. Systematic literature review provided detailed insight with respect to servant leadership theory and its outcomes which led to the development of taxonomy which was further used to develop integrated model of causal flow through mediating and moderating mechanisms; and then was further refined to identify servant leadership interaction with different organization and behavioral variables. Findings of this research suggest possible impact of servant leadership in power distant culture which is inconsistent in contemporary research and needs to be investigated for validation of servant leadership's concept in third world countries.
\end{abstract}

Keywords: Servant leadership, Job satisfaction, Organizational commitment

1- Institute of Business Management (IoBM), Senior Lecturer, Institute of Business Management, email: azeem.qureshi.iobm@gmail.com

2- Institute of Business Management (IoBM), Senior Lecturer, Institute of Business Management email: abdurrahmanjan@gmail.com

3- Institute of Business Management,Dean, email: dr.irfanhyder@gmail.com 
IBT Journal of Business Studies Volume 15(1), 2019

\section{INTRODUCTION}

Failure of well-known companies such as Enron, Tyco, WorldCom and many others in the world is more or less associated with leadership. Therefore emergence of value-laden leadership comes as no surprise (Sendjaya, Sarros, \& Santora, 2008). Servant leadership is another addition in the existing leadership literature. The term "servant leadership" was coined by Greenleaf (1970) who got inspiration from the novel "The Journey to the East" which anchored Eastern thoughts and Christian values (Hess, 1956) and made the core theme "going beyond one's self-interest". Greenleaf claimed in his seminal essay that servant leader has the natural tendency to serve first and then learn to lead as a servant leader(Greenleaf, 1977). Servant leadership has been described as a way of life, not as a management technique (Greenleaf, 1977; Greenleaf \& Spears, 1998).

Research on servant leadership has been overlooked after its origination until the last decade. Even today the theory of servant leadership is in its early stages and yet to be legitimated as a mainstream leadership theory by applying theory-testing approach in different cultural and organizational contexts (Chiniara \& Bentein, 2016).

\section{METHODOLOGY}

The general criterion employed for this systematic literature survey includes (a) research articles, books and seminal essays, (b) published in English, (c) all research articles have been published in impact factor journals, (d) belong to western and eastern context, (e) based on hypotheses testing approach, (f) measuring direct impact of servant leadership on various individual and organizational outcomes (f) along with mediating and moderating effects of different factors.

This systematic literature focuses on inclusion of available literature on servant leadership in Asian context, particularly Pakistani perspective. The study has been carried out in three phases. First phase is concerned with screening of abstracts and citations related to variable of interests, in second phase, peer discussion was made to retain valuable literature and exclusion of literature which does not fall in set criterion. In third phase, full text of articles and relevant literature were reviewed which were potentially related to and are of interest. The review process was carried out in weekly meetings between the authors that lasted for 7 months.

The data extracted from selected literature includes (a) study design, (b) sample size, (c) sampling approach, (d) country of origin, (e) measuring scales used in studies (f) mechanism through which independent variables exert their impact on dependent variables, $(\mathrm{g})$ statistical analysis $(\mathrm{h})$ key finding (i) implications, (j) future scope of the study and ultimately (k) thesis statement extracted from the study. This study reviewed each selected study to maintain methodological quality by adopting quality assessment tools which have been employed previously to perform systematic literature review in the domain of leadership (Cummings et al., 2010). In order to synthesize the literature addressing servant leadership and its influence on employee-related and organizational outcomes, this study analyzed the literature using descriptive approach as proposed by Turnnidge \& Côté (2016). On the basis of common characteristics, descriptive approach sorts information into thematic categories such as research design, instruments used to measure data and sample's characteristics etc. 


\section{OPERATIONALIZATION AND EVOLUTION OF SERVANT LEADERSHIP CONCEPT}

There is no consensus among research scholars on a single construct of servant leadership. There seems to be more differentiation then integration of scholars when it comes to operationalization of servant leadership in the existing literature. Based on mostly accepted doctrine of Greenleaf (1970, 1972) and Spears $(1995,2002)$, many attempts have been made to develop servant leadership constructs (Barbuto \& Wheeler, 2006).

For instance, Laub (1999) enriched the concept by identifying its six characteristics which include i) giving value to people that includes listen to them with respect, serving their needs and believing them; ii) people development that includes providing learning opportunities to subordinates, encouraging them and modeling appropriate behavior; iii) community building that refers to strong relationship building, collaborative building and giving value to individual differences, iv) authentic behavior which refers to trust, integrity, accountability, openness and amiability to learn from others; v) providing leadership which refers to envisioning the future, clarifying the future and taking initiative; vi) sharing leadership which includes development of shared vision and sharing the power and decision making.

Similarly, Ehrhart (2004) made significant contribution by developing the simplest and reliable means to measure the servant leadership concept through two main constructs namely i) ethical behavior and ii) concern for subordinates.

(Barbuto et al., 2006) identified eleven dimensions of servant leadership which were refined into five including i) wisdom refers to awareness of environment and anticipation of its consequences and implications. ii) Altruistic calling refers to ambition to make positive difference in one' life. iii) Emotional healing can be described as leader's ability to be empathetic and great listener and facilitating followers to recover from hardships. iv) Persuasive mapping is about sound reasoning. v) Organizational stewardship refers to community development by making positive contribution to society from organization.

Sendjaya et al. (2008) suggested six dimensions of servant leadership namely voluntary subordination which refers to serving others, authentic self consists of humility, integrity, accountability, security and vulnerability, covenantal relationship refers to acceptance, availability, equality and collaboration, responsible morality contains religiousness, interconnectedness, sense of mission and wholeness. The last component of this construct is transforming influence that encompasses vision, modeling, mentoring, trust and empowerment.

It has been claimed that instrument to measure servant leadership closer to Greenleaf's proposed model and encompassing full breath of the concept is the servant leadership survey (SLS) developed by Van Dierendonck \& Nuijten (2011). This scale captures the servant leadership concept with eight dimensions, namely empowerment which refers to ownership of responsibility for the work, accountability which refers to holding one responsible for the action he or she carried out, standing back is about letting others shine and working in background, humility refers to with humble attitude and combined integrity, authenticity is presenting one's true self without any exaggeration, courage is willingness for taking risk, forgiveness refers to releasing resentment and stewardship refers to behaving ethically. 
IBT Journal of Business Studies Volume 15(1), 2019

\section{SERVANT LEADERSHIP \& TRANSFORMATIONAL LEADERSHIP}

However there are many similar characteristics between transformational and servant leadership (Ehrhart, 2004) and both the leadership styles are strongly correlated (Schneider \& George, 2011), what makes servant leadership different is the moral responsibility to serve which is absent in transformational leadership. Secondly, Servant leaders put followers' need first, organizations' need second and their own needs at last (Graham, 1991; Stone et al., 2004). Transformational leaders inspire their followers in pursuit of organizational goals while servant leaders focus on individuals' service which supersedes organizational objectives (Barbuto \& Wheeler,2006; Choudhary, Akhtar, $\&$ Zaheer, 2013). Servant leadership is a better predictor of followers' attitudes and perishes the effect of other leadership (transformational) style when comes in action particularly in non-profit organizations (Schneider \& George, 2011). However transformational leadership is a better predictor organizational learning i.e. the process of gathering, sharing and interpreting information to gain competitive advantage and better organizational performance (Slater, 1995), than servant leadership that leads to better financial performance (Choudhary et al., 2013). These findings are in alignment with the argument that servant leadership is less effective in power distant cultures (Donia et al., 2016; Van Dierendonck \& Nuijten, 2011).

\section{SERVANT LEADERSHIP AND AUTHENTIC LEADERSHIP}

Servant leaders and authentic leaders both focus on development of followers. In the same fashion, they have greater sense of their selves; they believe in self-regulation and prioritize positive moral perspective i.e. authenticity (Avolio \& Gardner, 2005). However it was argued by Avolio \& Gardner, (2005) that self-regulation and self-awareness are the missing components in servant leadership but later studies overcome this deficiency (e.g. Barbuto et al., 2006; Dennis \& Bocarnea, 2005; Laub, 2003; Whittington et al., 2006; Wong \& Page, 2003). What makes servant leadership different from authentic leadership, ethical leadership and moral leadership is servant leaders' devotion to strive for the well-being of followers and all stakeholders of organization (Greenleaf, 1977).

\section{SERVANT LEADERSHIP AND ETHICAL LEADERSHIP}

Ethical leadership has been defined as "the demonstration of normatively appropriate conduct through personal actions and interpersonal relationships, and the promotion of such conduct to followers through two-way communication, reinforcement, and decision-making" (Brown, Treviño, \& Harrison, 2005). One of the core theme of servant leadership is "behaving ethically" which infers that relationship between servant leaders and their followers is fair, open and honest (Liden et al., 2008). Since virtues, morality and ethics are associated with servant leadership, overlapping between ethical and servant leadership is quite obvious (Parris \& Peachey, 2013). Ethical leaders put emphasis on execution of organizational tasks according to the norms of the organization while servant leaders focus on development of their followers. However there is an overlap between ethical and servant leadership, what makes servant leaders more distinct is their focus on personal aspects of one's life such as concern for community and emotional healing which are overlooked in ethical leadership (Dierendonck, 2011).

\section{SERVANT LEADERSHIP AND ITS OUTCOMES}

Servant leaders do not only listen to people, but also support them with the intention of their development. By doing so, servant leaders enhance their subordinate's capacity to take on 
creative approach with greater responsibilities at workplace (Stone \& Patterson, 2005). The needs of subordinates are in priority of a servant leaders who put emphasis on personal development and empowerment of their subordinates. In this respect, servant leaders believe in one-to-one communication to understand subordinates' full potential. Focus of servant leaders is on each of their follower so that potential of each follower can be realized. Servant leaders satisfy the needs of autonomy of their followers. Empowering followers and liberating them to handle difficult situations, learning from mistakes, encouraging followers to be creative, making decisions on their own and providing followers supporting environment to exercise their full potential are the some of the key function servant leaders perform (Liden et al., 2008).

Servant leaders invest great deal of energy and time to understand career goals, interest and capabilities of their followers (Greenleaf \& Spears, 1998). Altruism, consciousness and simplicity are characteristics of servant leaders (Johnson, 2012). Since serving the followers is the supreme priority of servant leaders, they craft an environment that provides opportunities for enhancing followers' present skills, growing new ones; thus they fulfill followers' need of competency (Liden et al., 2008).Servant leaders build trustworthy dyadic relationship with their subordinates when they demonstrate altruistic behavior, hence fulfilling relatedness need of followers (Ehrhart, 2004).

Servant leaders manage quality relationships by providing more caring experience to their followers (Greenleaf \& Spears, 2002) which, along with sense of moral responsibility and respect given by servant leaders, helps subordinates to grow (Greenleaf, 1997). The primary motivation of servant leader is not to lead, but desire to lead comes because of need of group success (Greenleaf, 1977). Servant leaders sacrifice their self-interest when serving the needs of followers (Whetstone, 2002). This serving attitude makes servant leaders role model to their followers (Babakus, Yavas, \& Ashill, 2010). Servant leaders try to instill the same serving behavior in their subordinates (Greenleaf \& Spears, 1998). Servant leaders believe that organizations comprise of individuals who are valuable resource and organizations can achieve their goals on long-term basis by growing, developing and taking care of well-being of these individuals (Stone et al., 2004).

Impact of servant leadership on different employee outcomes is consistent in different organizational settings. For instance in schools, teachers' job satisfaction is enhanced when principals demonstrate authentic behavior and teachers feel being valued, more important than the job and as a result, principals are viewed trustworthy by teachers (Oplatka, 2004). Findings of the study carried out in primary schools situated in Turkey revealed significant positive impact of principals' servant leadership behavior on teachers' job satisfaction. Since decreased job satisfaction leads to disappointment, absenteeism, decreased performance and increased turnover (Evans and Jonhson, 1990; Rahim and Afza, 1993; Igbaria and Guimaraes, 1999; Cetinkanat, 2002),instilling servant leadership behavior in schools principals can results in increased job satisfaction which leads to better organizational outcome (Cerit, 2009). There are empirical evidences that organizational resources create impact on various job outcomes (Lee \& Ashforth, 1996; Schaufeli \& Bakker, 2004). Servant leadership as an organizational resource, has significant impact on burnout and turnover intention directly and through mediation of person-job fit (Babakus et al., 2010).

Servant leaders, through empowering their followers, promote job satisfaction and organizational commitment which lead to encourage employee retention. Servant leaders foster these positive employee and organizational outcome better than transformational leaders (Schneider \& George, 2011). It has been experienced that servant leaders, through their serving behavior gain trust from their subordinates that also results in job satisfaction (CH Chan \& Mak, 2014). 
Servant leaders believe in open communication. They treat followers with respect, politeness and through honest and adequate explanations about decisions about procedures employed. By doing so, servant leaders instill feelings of justice in their followers, which as a result generates optimism which leads followers to accept change (Kool \& van Dierendonck, 2012) since change, whether internal or external, is inevitable in the changing dynamics of the corporate world (Vermeulen, Puranam, \& Gulati, 2010).

Servant leadership, being people-oriented, creates positive impact on followers' personal lives (Zhang et al., 2012). According to conservation of resource theory, individuals need resources (physical, social and psychological) in order to fulfil needs of their daily lives. Therefore they strive to retain and protect these resources (Hobfoll, 1989). Psychological and social resources play a key role in handling stressful working conditions. On the other hand, theory of work-family enrichment proposes that the experience in one role (e.g. at workplace) improves the quality of life in other role (e.g. role in family). If employees are provided not enough social and psychological resources at workplace such as self-esteem and self-efficacy, stress is created and results in work-family conflict (Greenhaus \& Powell, 2006). Supporting followers with emotional healing, guidance and empowerment, servant leadership reduces cynicism, work-family conflict and makes positive impact on the lives of followers because servant leadership makes followers able to transfer positive values and behaviors from workplace to their homes (Hanson et al., 2006; Tang et al., 2015). Thus, using the social learning theory mechanism, servant leadership reduces work-family conflicts.

Servant-hood in leadership varies with respect to change in culture. Particularly in power distant culture, it has inconsistent outcomes. It is evident that mean level of servant leadership is lower in power distant culture particularly in three dimensions of servant leadership as proposed by Dierendonck \& Nuijten (2011) which are standing back, authenticity and humility. Even in power distant culture, impact of servant leadership is inevitable and cannot be ignored.

Servant leaders cultivate a sense of community by nurturing team members' well-being. This creates a sense of security, safety and perception of normative behavior expectations from leaders (Cooper $\&$ Thatcher, 2010). Such followers strongly identify themselves with their leaders (Aryee, et al., 2007) which results in increased intrinsic motivation leading to successful efforts in goal attainment. Servant leaders, through positively enhancing individual and collective leader identification, encourage creativity. This creativity is indifferent in Western and Asian culture (Yoshida et al., 2014).

Social learning theory proposes that people learn by observing the behavior of others and replicating it (Bandura \& McClelland, 1977). Demonstration of ethical behavior, concern for subordinates and high level of integrity by servant leaders which are viewed as positive and desirable by others, help followers to model the servant behavior. Followers, as a consequence, emulate the behavior of their leaders and become servant as well. Servant behavior of followers permeates throughout the organization and becomes the norm; and ultimately it becomes the "culture" of organization. This "serving culture" affects followers positively, not only at individual or dyadic level but also at the unit level. Followers start having sense of belonging and cognitive attachment with the organization (Ashforth \& Mael, 1989), resulting in increased individual and organizational performance (Liden et al., 2014).

Servant leadership enhances task performance and organizational citizenship behavior i.e. a behavioral tendency to seek tasks beyond one's job description and without any formal reward 
(Organ, 1988) of followers at individual and organizational level through fulfilling three basic psychological needs of follower namely autonomy, competence and relatedness which are the nutriments of self-determination theory (Chiniara \& Bentein, 2016). Further, positive association of servant leadership with organizational commitment and organizational citizenship behavior (OCB) has been observed. While there is a negative association of servant leadership with cynicism (a core component of job burnout) and these findings are consistent in both profit and non-profit organizations (Bobbio et al., 2012).Leader-member exchange (a theory proposes that followers reciprocate the treatment they receive from leader to maintain equitable social-exchange) provides the mediating mechanism through which servant leadership translates its impact on organizational citizenship behavior (Newman et al., 2015; Wu et al., 2013). Furthermore, proactive personality i.e. a behavioral tendency that helps identifying opportunities to implement change, also moderates the impact of servant leadership on OCB (Newman et al., 2015). People who are more sensitive to respond to other's treatment experience stronger impact of servant leadership on OCB (Wu et al., 2013). OCB of followers is also affected by their motives. Followers with self-serving motives do not exhibit OCB while followers with selfless motives have stronger impact of servant leadership behavior on their OCB, implying that the benefits of servant leadership may not the same for all followers (Donia et al., 2016).

\section{CONCLUSION}

Servant leadership is a unique construct that has many matchless characteristics. These matchless characteristics make servant leadership different from other seasoned leadership styles. Concern for subordinates with respect to their needs' fulfillment is the most pervasive among these characteristics. After its initiation, the term 'servant leadership' got little attention of scholars until the last decade when the idea of servant leadership got its place as a mainstream leadership style.

Many attempts have been made to operationalized servant leadership concept. We have more than five scales to measure servant leadership. These scales have different dimension of servant leadership. This difference in conceptualization of servant leadership is itself a significant gape that needs to be filled by research community. Why don't we come up with one comprehensive construct that encompasses the essence of servant leaderships proposed by its originator i.e. Greenleaf? is the question which is to be answered. It is argued that instrument developed by Dierendonck \& Nuijten (2011) is the closest to Greenleaf's concept of servant leadership.

Similarities between servant leadership and other leadership styles such as transformational leadership, authentic leadership and ethical leadership blur the uniqueness of these constructs. Research scholars have paid little attention in this regard. Resolving and maintaining uniqueness and distinctiveness of the constructs is an obligation of research community. The systematic literature survey gives a clear direction to fill this gape.

People orientation of servant leadership helps subordinates determining their full potential. Furthermore, servant leaders encourage subordinates to take on challenges; and through empowering and providing autonomy, servant leaders make sure psychological empowerment and development of their followers. Servant leadership builds trust of followers through self-sacrifice, providing caring experience and respect to subordinates as well as treating subordinates as an important organizational resource. Servant leadership is a good predictor of individual and organizational financial and non-financial performance. Servant behavior decreases emotional exhaustion, cynicism and hence job burnout which reduces work family conflicts, turnover intention among followers. Servant leadership generates perception of justice and optimism in followers which help followers to adapt organizational change. 
IBT Journal of Business Studies Volume 15(1), 2019

However these outcomes are subject to mediation of leader-member exchange, social learning, selfdetermination and leader identification theories. Effects of servant leadership are further moderated by motives of followers, sensitivity to treatment given to followers, proactive personality and person-job fit. Organizational citizenship behavior, job satisfaction and turnover intention are the most examined variables in the existing literature of servant leadership.

Servant leadership's impact in power distance culture is inconsistent. Authority is normally centralized in power distance culture where followers are accustomed to autocratic leadership style. There exists some sort of ambiguity from followers' side about how to respond servant behavior from leader which needs to be addressed and could be a possible future extension. The significant contribution that this paper makes, is that it provides an insight about variables and their relationship used in recent researches with reference to servant leadership in the form of a taxonomy and develops an integrated model of causal flow through moderation and mediation mechanisms along with the variables and their definitions as presented below.

\section{Taxonomy}

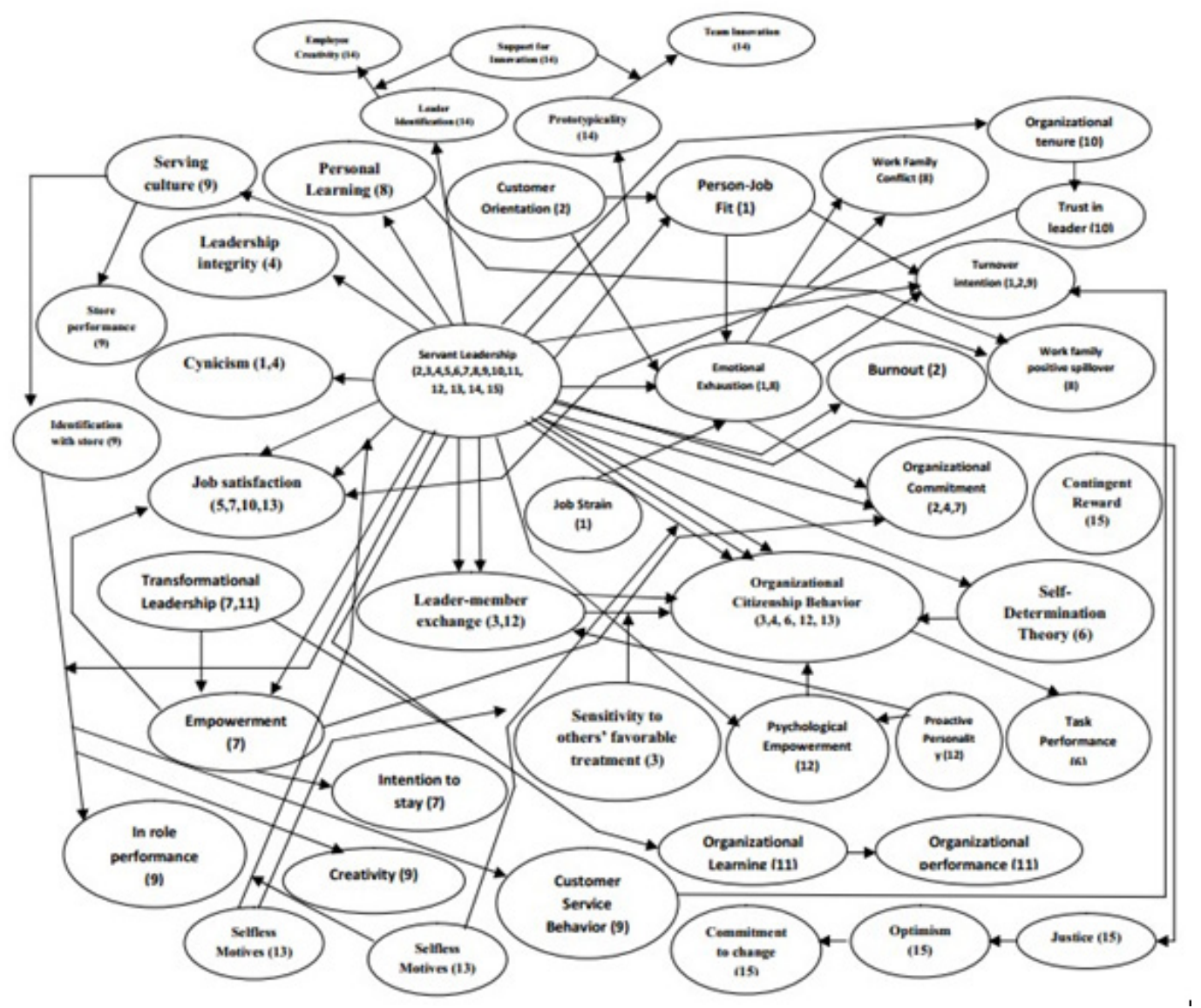




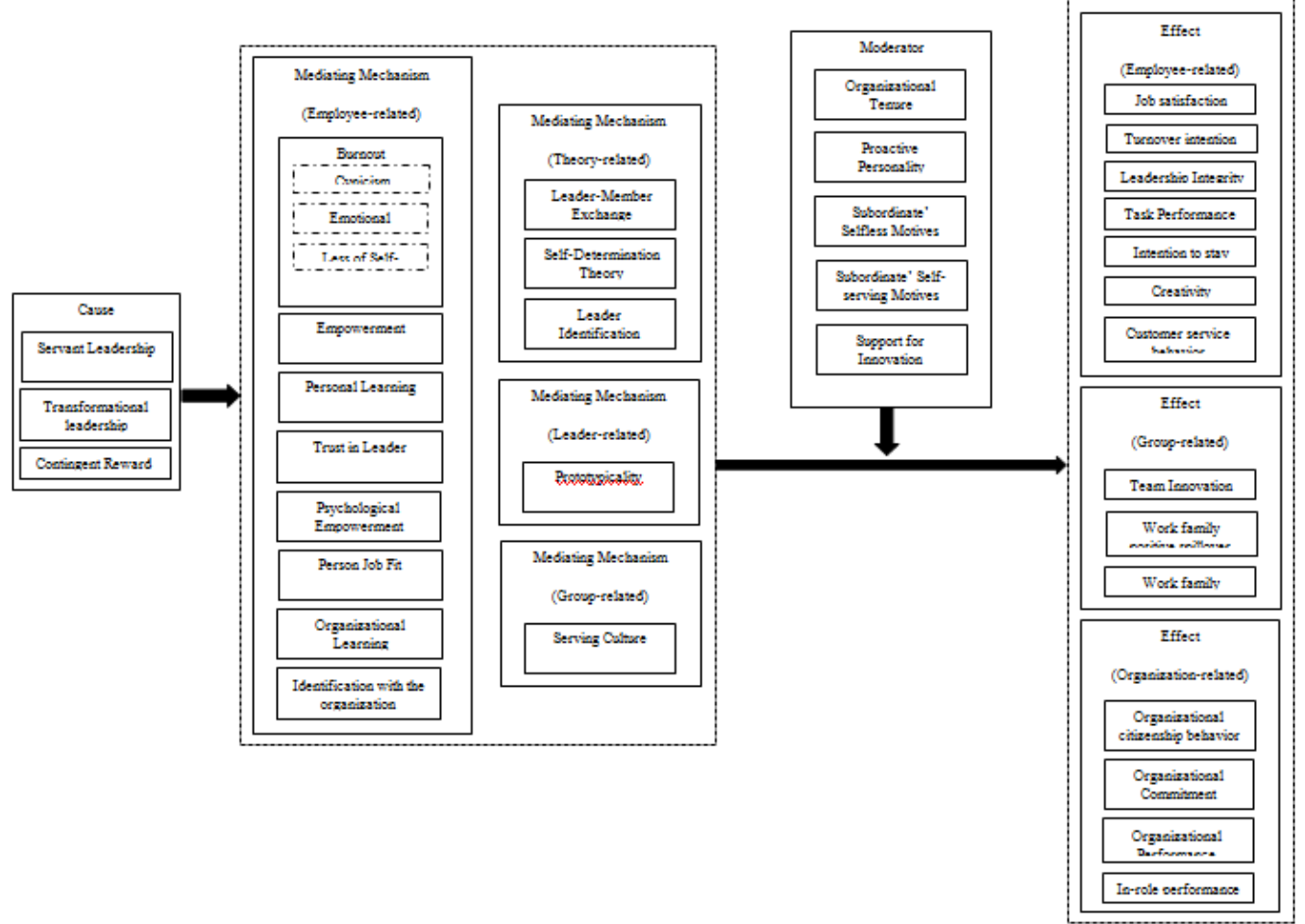

\section{REFERENCES}

Aryee, S., Chen, Z. X., Sun, L.-Y., \& Debrah, Y. A. (2007). Antecedents and outcomes of abusive supervision: test of a trickle-down model. Journal of Applied Psychology, 92(1), 191.

Ashforth, B. E., \& Mael, F. (1989). Social identity theory and the organization. Academy of Management Review, 14(1), 20-39.

Avolio, B. J., \& Gardner, W. L. (2005). Authentic leadership development: Getting to the root of positive forms of leadership. The Leadership Quarterly, 16(3), 315-338.

Babakus, E., Yavas, U., \& Ashill, N. J. (2010). Service worker burnout and turnover intentions: Roles of person-job fit, servant leadership, and customer orientation. Services Marketing Quarterly, 32(1), 17-31.

Bandura, A., \& McClelland, D. C. (1977). Social learning theory.

Barbuto, J. E., Wheeler, D. W., \& others. (2006). Scale development and construct clarification of servant leadership. Group \& Organization Management, 31(3), 300-326.

Bobbio, A., Van Dierendonck, D., \& Manganelli, A. M. (2012). Servant leadership in Italy and its relation to organizational variables. Leadership, 8(3), 229-243.

Brown, M. E., Treviño, L. K., \& Harrison, D. A. (2005). Ethical leadership: A social learning perspective for construct development and testing. Organizational Behavior and Human Decision Processes, 97(2), 117-134.

Cerit, Y. (2009). The effects of servant leadership behaviours of school principals on teachers' job satisfaction. Educational Management Administration \& Leadership, 37(5), 600-623. 
IBT Journal of Business Studies Volume 15(1), 2019

CH Chan, S., \& Mak, W. (2014). The impact of servant leadership and subordinates' organizational tenure on trust in leader and attitudes. Personnel Review, 43(2), 272-287.

Chiniara, M., \& Bentein, K. (2016). Linking servant leadership to individual performance: Differentiating the mediating role of autonomy, competence and relatedness need satisfaction. The Leadership Quarterly, 27(1), 124-141.

Choudhary, A. I., Akhtar, S. A., \& Zaheer, A. (2013). Impact of transformational and servant leadership on organizational performance: A comparative analysis. Journal of Business Ethics, $116(2), 433-440$.

Cooper, D., \& Thatcher, S. M. (2010). Identification in organizations: The role of self-concept orientations and identification motives. Academy of Management Review, 35(4), 516-538.

Cummings, G. G., MacGregor, T., Davey, M., Wong, C. A., Lo, E., Muise, M., \& Stafford, E. (2010). Leadership styles and outcome patterns for the nursing workforce and work environment: a systematic review. International Journal of Nursing Studies, 47(3), 363-385.

Dennis, R. S., \& Bocarnea, M. (2005). Development of the servant leadership assessment instrument. Leadership \& Organization Development Journal, 26(8), 600-615.

Donia, M. B., Raja, U., Panaccio, A., \& Wang, Z. (2016). Servant leadership and employee outcomes: the moderating role of subordinates' motives. European Journal of Work and Organizational Psychology, 1-13.

Ehrhart, M. G. (2004). Leadership and procedural justice climate as antecedents of unit-level organizational citizenship behavior. Personnel Psychology, 57(1), 61-94.

Graham, J. W. (1991). Servant-leadership in organizations: Inspirational and moral. The Leadership Quarterly, 2(2), 105-119.

Greenhaus, J. H., \& Powell, G. N. (2006). When work and family are allies: A theory of workfamily enrichment. Academy of Management Review, 31(1), 72-92.

Greenleaf, R. K. (1970). The Servant as Leader, The Robert K. Greenleaf Center, Indianapolis, IN.

Greenleaf, R. K. (1977). Servant leadership. New York: Paulist Press.

Greenleaf, R. K. (1997). The servant as leader. University of Notre Dame Press. Retrieved from http://psycnet.apa.org/psycinfo/1997-36918-026

Greenleaf, R. K., \& Spears, L. C. (1998). The power of servant-leadership: Essays. Berrett-Koehler Publishers.

Greenleaf, R. K., \& Spears, L. C. (2002). Servant leadership: A journey into the nature of legitimate power and greatness. Paulist Press.

Gregory Stone, A., Russell, R. F., \& Patterson, K. (2004). Transformational versus servant leadership: A difference in leader focus. Leadership \& Organization Development Journal, 25(4), 349-361.

Hanson, G. C., Hammer, L. B., \& others. (2006). Development and validation of a multidimensional scale of perceived work-family positive spillover. Journal of Occupational Health Psychology, 11(3), 249.

Hess, H. (1956). The journey to the east. New York: Farrar Straus Giroux.

Hobfoll, S. E. (1989). Conservation of resources: A new attempt at conceptualizing stress. American Psychologist, 44(3), 513.

Johnson, C. E. (2012). Meeting the Ethical Challenges of Leadership. Retrieved from http://www. tcrecord.org/library/Abstract.asp?ContentId=12235

Kool, M., \& van Dierendonck, D. (2012). Servant leadership and commitment to change, the mediating role of justice and optimism. Journal of Organizational Change Management, 25(3), $422-433$.

Laub, J. (2003). From paternalism to the servant organization: Expanding the Organizational Leadership Assessment (OLA) model. In Proceedings of the Servant Leadership Research Roundtable. 
Laub, J. A. (1999). Assessing the servant organization: Development of the servant organizational leadership (SOLA) instrument. Florida Atlantic University. Dissertation Abstracts International (ProQuest Digital Dissertations), 60(02).

Lee, R. T., \& Ashforth, B. E. (1996). A meta-analytic examination of the correlates of the three dimensions of job burnout. Journal of Applied Psychology, 81(2), 123.

Liden, R. C., Wayne, S. J., Liao, C., \& Meuser, J. D. (2014). Servant leadership and serving culture: Influence on individual and unit performance. Academy of Management Journal, 57(5), 1434 1452.

Liden, R. C., Wayne, S. J., Zhao, H., \& Henderson, D. (2008). Servant leadership: Development of a multidimensional measure and multi-level assessment. The Leadership Quarterly, 19(2), 161-177.

Newman, A., Schwarz, G., Cooper, B., \& Sendjaya, S. (2015). How servant leadership influences organizational citizenship behavior: The roles of LMX, empowerment, and proactive personality. Journal of Business Ethics, 1-14.

Organ, D. W. (1988). Organizational citizenship behavior: The good soldier syndrome. Lexington Books/DC Heath and Com.

Parris, D. L., \& Peachey, J. W. (2013). A systematic literature review of servant leadership theory in organizational contexts. Journal of Business Ethics, 113(3), 377-393.

Schaufeli, W. B., \& Bakker, A. B. (2004). Job demands, job resources, and their relationship with burnout and engagement: A multi-sample study. Journal of Organizational Behavior, 25(3), 293-315.

Schneider, S. K., \& George, W. M. (2011). Servant leadership versus transformational leadership in voluntary service organizations. Leadership \& Organization Development Journal, 32(1), $60-77$.

Sendjaya, S., Sarros, J. C., \& Santora, J. C. (2008). Defining and measuring servant leadership behaviour in organizations. Journal of Management Studies, 45(2), 402-424.

Slatersf, N. J. C. (1995). Market Orientation andtheLearning Organisation. Journalof MarKeting, $59(3), 63-74$.

Stone, A. G., \& Patterson, K. (2005). The history of leadership focus. In Servant Leadership Research Roundtable Proceedings.

Tang, G., Kwan, H. K., Zhang, D., \& Zhu, Z. (2015). Work-family effects of servant leadership: The roles of emotional exhaustion and personal learning. Journal of Business Ethics, 1-13.

Turnnidge, J., \& Côté, J. (2016). Applying transformational leadership theory to coaching research in youth sport: A systematic literature review. International Journal of Sport and Exercise Psychology, 1-16.

Van Dierendonck, D. (2011). Servant leadership: A review and synthesis. Journal of Management, 37(4), 1228-1261.

Van Dierendonck, D., \& Nuijten, I. (2011). The servant leadership survey: Development and validation of a multidimensional measure. Journal of Business and Psychology, 26(3), 249-267.

Vermeulen, F., Puranam, P., \& Gulati, R. (2010). Change for change's sake. Harvard Business Review, 88(6), 70-76.

Whetstone, J. T. (2002). Personalism and moral leadership: The servant leader with a transforming vision. Business Ethics: A European Review, 11(4), 385-392.

Whittington, J. L., Frank, B. A., May, R. C., Murray, B., \& Goodwin, V. (2006). Servant leadership in organizations: Scale development and validation. In Academy of Management Meeting, Atlanta, GA.

Wong, P. T., \& Page, D. (2003). Servant leadership: An opponent-process model and the revised servant leadership profile. In Proceedings of the Servant Leadership Research Roundtable. 


\section{Citeseer.}

Wu, L.-Z., Tse, E. C.-Y., Fu, P., Kwan, H. K., \& Liu, J. (2013). The impact of servant leadership on hotel employees" "servant behavior." Cornell Hospitality Quarterly, 54(4), 383-395.

Yoshida, D. T., Sendjaya, S., Hirst, G., \& Cooper, B. (2014). Does servant leadership foster creativity and innovation? A multi-level mediation study of identification and prototypicality. Journal of Business Research, 67(7), 1395-1404.

Zhang, H., Kwong Kwan, H., Everett, A. M., \& Jian, Z. (2012). Servant leadership, organizational identification, and work-to-family enrichment: The moderating role of work climate for sharing family concerns. Human Resource Management, 51(5), 747-767. 